\title{
Endoscopic examination of the nasal cavity and nasopharynx in patients with otitis media
}

\author{
Otitis media hastalarında nazal kavite ve nazofarenksin endoskopik incelemesi
}

\author{
Cenk Evren, ${ }^{1}$ İlter Tezer ${ }^{2}$ \\ ${ }^{1}$ Department of Otolaryngology, Beylikdüzü Medilife Hospital, İstanbul, Turkey \\ ${ }^{2}$ Department of Otolaryngology, Gebze Fatih State Hospital, Kocaeli, Turkey
}

\begin{abstract}
Objectives: This study aims to identify nasal and nasopharyngeal pathologies using rigid transnasal endoscopy and to investigate the possible relationship between these pathologies and otitis media.

Patients and Methods: A total of 103 patients (55 males, 48 females; mean age 30.1 years; range 4 to 72 years) with various types of otitis media were compared with age and sex-matched 124 controls (56 males, 68 females; mean age 20.5 years; range 4 to 72 years). The clinical type of ear disease, and nasal and nasopharyngeal findings were obtained by rigid transnasal endoscopy. Nasal endoscopy was performed with 0 degree, 4 or $2.7 \mathrm{~mm}$ diameter rigid telescopes. The otoscopy was performed with operating microscopes. Statistical analysis was performed using the Student's t test.
\end{abstract}

Results: Edema at the nasopharyngeal opening of the Eustachian tube and purulent secretion in nasopharynx were the most common findings in all patients with otitis media. Sinusitis was significantly higher in children with otitis media with effusion (OME) and suppurative chronic otitis media (COM). Septal deviation was only significantly higher in patients with COM. Pressure of adenoid tissue on tuba opening was more frequent in children with OME and inactive COM; however, it did not reach statistical significance.

Conclusion: Our study results revealed a relationship between the type or form of the COM and nasopharynx and nasal pathologies. Suppurative forms of otitis media, in particular, may be significantly associated with infectious nasal and nasopharyngeal pathologies and edema of the Eustachian tube opening.

Key Words: Nasopharynx; otitis media; transnasal endoscopy.

\begin{abstract}
Amaç: Bu çalışmada, rijit transnazal endoskopi ile nazal ve nazofarengeal patolojiler belirlendi ve bu patolojiler ve otitis media arasındaki olası ilişki araştırıldı.
\end{abstract}

Hastalar ve Yöntemler: Çeşitli otitis media rahatsızlığ olan toplam 103 hasta (55 erkek, 48 kadın; ort. yaş 30.1 yıl; dağılım 4-72 yıl), yaş ve cinsiyet eşleştirilmiş 124 kontrol (56 erkek, 68 kadın; ort. yaş 20.5 yıl; dağılım 4-72 yıl) ile karşılaştırıldı. Kulak hastalığının klinik tipi ve nazal ve nazofarengeal bulgular rijit transnazal endoskopi ile belirlendi. Nazal endoskopide 0 derece, 4 veya $2.7 \mathrm{~mm}$ çapındaki rijit teleskoplar kullanıldı. Ameliyat mikroskopları ile otoskopi yapıldı. İstatistiksel analizde Student t testi kullanıldı.

Bulgular: Otitis media hastalarında en sık bulgular östaki tüpünün nazofarengeal ağzında ödem ve nazofarenkste pürülan sekresyondu. Efüzyonlu otitis media (EOM) ve süpüratif kronik otitis media (KOM) olan çocuklarda sinüzit anlamlı olarak yüksekti. Septum deviyasyonu yalnızca KOM hastalarında anlamlı düzeyde yüksekti. Tuba ağzındaki adenoid doku basısı, EOM ve inaktif KOM olan çocuklarda daha sıktı; ancak, bu istatistiksel olarak anlamlı değildi.

Sonuç: Çalışma bulgularımız, KOM tipi veya formu ile nazal ve nazofarenks patolojileri arasında bir ilişki olduğunu gösterdi. Özellikle otitis medianın süpüratif formları nazal ve nazofarenks enfeksiyonları ve östaki tüpü ağzında ödem ile anlamlı düzeyde ilişkiliydi.

Anahtar Sözcükler: Nazofarenks; otitis media; transnazal endoskopi. 
Otitis media with effusion (OME) is a chronic disease which is characterized by conductive hearing loss, persisting type-B tympanograms, special otoscopic findings, and painless aural fullness, accompanied by mental problems in some cases. ${ }^{[1,2]}$

Nasal and nasopharyngeal pathologies have long been recognized as important factors in the pathogenesis of otitis media. It has been traditionally hypothesized that a mass in the nasopharynx causes an obstacle to airflow through the Eustachian tube (ET), thereby a negative pressure in the middle ear followed by an effusion. ${ }^{[3]}$ The nasopharyngeal pathology represents a potential danger for middle ear ventilation. An obstructed nasal passage is also considered likely to hamper middle ear ventilation. ${ }^{[3]}$

Although dysfunction of the ET has been widely acknowledged as one of the important causes of OME, it remains to be elucidated. ${ }^{[3]}$ Suzuki et al. ${ }^{[4]}$ reported that adenoid inflammation was implicated in the pathogenesis of OME and adenoids might play a critical role in the etiology of OME, as being a reservoir for Haemophilus influenza.

Although the pathogenesis of chronic suppurative otitis media is unknown, chronic ET dysfunction due to chronic or recurrent nose as well as throat infections or anatomical tubal obstructions have been implicated in the chronicity of suppurative otitis media. ${ }^{[5]}$

An underlying absence of middle ear aeration due to ET dysfunction is also considered to be a culprit for cholesteatomas, chronic tympanic membrane perforation and atelectasis. ${ }^{[5]}$

Endoscopic examination offers direct visualization of the nasal and nasopharyngeal space as well as of the size and condition of the adenoid tissue, the condition of the nasopharyngeal orifice of the ET and the pathology of septum and turbinates. The area of the nasopharynx has been measured by several methods. Recently, endoscopy is accepted as the gold standard in nasal and nasopharyngeal examination. ${ }^{[6]}$

In this study, we aimed to identify nasal and nasopharyngeal pathologies using rigid transnasal endoscopy and to investigate the possible relationship between these pathologies and otitis media.

\section{PATIENTS AND METHODS}

Informed consents were obtained from all patients. The study protocol was approved by the Bakırköy Sadi Konuk Research and Training Hospital Ethical Committee. The study was conducted according to the Declaration of Helsinki.
This study enrolled a total of 103 patients including 27 children (48 ears) with OME, nine adults (14 ears) with OME, and 67 patients (77 ears) (55 males, 48 females; mean age 30.07 years; range 4 to 72 years) who were admitted to the Otolaryngology Outpatient Clinic, Beylikdüzü Medilife Hospital and Gebze Fatih State Hospital with chronic otitis media (COM) between January 2011 and January 2012. The control group consisted of a total of 124 children and adults (56 males, 68 females; mean age 20.5 years; range 4 to 72 years). Rigid endoscopy was carried out in all cases of all ages without any problem. Otoscopic examination was carried out and the results were recorded in patients who were diagnosed with otitis media by ENT examination and medical history. The "Zeiss Pica operating microscope" was used and transnasal endoscopy was performed in sitting position topical anesthesia with $10 \%$ lidocain was administered to some patients. A rigid 0 degree 2.4 and $4 \mathrm{~mm}$ telescope (Karl Storz Endoscope, Tuttlingen, Germany) was used to obtain pathological findings. Screenings were recorded to the computer by using the Aver Media capture card (Aver Media Technologies Inc., USA).

Otomicroscopic findings were classified as OME, characterized by increased vascularization in the tympanic membrane, retraction, and fluid-air reflection.

Chronic otitis media with cholesteatoma presented with perforation of tympanic membrane and cholesteatoma material, as well as granulation tissue and suppuration. Inactive COM was defined as perforation of TM tympanosclerosis without suppuration and cholesteatoma, while suppurative COM was defined as perforation of TM with suppuration and without cholesteatoma. The controls had no ear pathologies.

Nasal cavity and nasopharynx were examined in terms of mucosal condition, anatomical variation and pathological findings. Findings were recorded and classified as septal deviation, concha hypertrophy, sinusitis, polyps, adenoid vegetation, tuba edema, purulent secretion, atrophy and tumoral mass.

Statistical analysis was performed using a paired Student's $t$ test.

\section{RESULTS}

The demographic data of the patients including age, sex, and ear condition of the corresponding ear are presented in Table 1. Nasal cavity and nasopharyngeal endoscopic findings are shown in Table 2. A comparison of the endoscopic findings of the patients with otitis media and controls in terms of is summarized in Table 3. 


\begin{tabular}{|c|c|c|c|c|c|}
\hline \multicolumn{6}{|c|}{$\begin{array}{c}\text { Table } 1 \\
\text { The demographic data of the patients }\end{array}$} \\
\hline Type of otitis media & Male/female & Number of patient & Number of ear & $\begin{array}{l}\text { Contra lateral ear } \\
\text { condition }\end{array}$ & $\begin{array}{l}\text { Mean age } \\
\text { (year) }\end{array}$ \\
\hline Children OME & $17 / 10$ & 27 & 48 & $\begin{array}{c}1 \mathrm{AOM}+\text { mastoiditis } \\
21 \text { OME } \\
1 \text { inactive } \\
4 \text { normal }\end{array}$ & 7.8 \\
\hline Adult OME & $4 / 5$ & 9 & 14 & $\begin{array}{l}4 \text { normal } \\
5 \text { OME }\end{array}$ & 53.4 \\
\hline COM with cholesteatoma & $13 / 9$ & 22 & 23 & $\begin{array}{c}11 \text { normal } \\
1 \text { cholesteatoma } \\
2 \text { inactive COM } \\
1 \text { suppurative COM } \\
3 \text { adhesive otitis } \\
3 \text { tympanosclerosis } \\
1 \text { mastoidectomy } \\
18 \text { normal } \\
6 \text { inactive COM } \\
\text { and timpansclerosis } \\
4 \text { adhesive otitis }\end{array}$ & 30.4 \\
\hline Inactive COM & $14 / 20$ & 34 & 40 & $\begin{array}{c}2 \text { intact timpansclerosis } \\
1 \text { suppurative } \\
1 \text { cholesteatoma } \\
1 \text { operated } \\
1 \text { OME }\end{array}$ & 25.2 \\
\hline Suppurative COM & $7 / 4$ & 11 & 14 & $\begin{array}{c}6 \text { normal } \\
3 \text { suppurative COM } \\
1 \text { inactive } \\
1 \text { mastoidectomy }\end{array}$ & 33.55 \\
\hline Control & $46 / 54$ & 100 & & & 33.6 \\
\hline Control children & $10 / 14$ & 24 & & & 7.4 \\
\hline
\end{tabular}

The illness was bilateral in $80 \%$ of the children with OME ( $\mathrm{n}=27,48$ ears) (Figure 1). Otitis media with effusion was more frequent in men. Mastoid complication in the corresponding ear was observed in one patient. Nasal and nasopharyngeal examination revealed a higher incidence of nasopharyngeal pathologies in children with OME compared to the control group.

Half of the adult patients with OME ( $\mathrm{n}=9,14$ ears) had bilateral OME. Tuba edema in the nasopharyngeal opening of the ET, adenoid tissue hypertrophy, purulent secretion and sinusitis were more frequent in these patients (Tables 2, 3). There were no differences in sex among the adult OME patients. The mean age of these patients was higher than those with other otitis types.
The number of male patients with cholesteatoma COM was higher. While the corresponding ear was normal in half of the patients, every type of clinical presentation of otitis media was observed in the other half (Table 1). The mean age was 30.4 years in COM patients with cholesteatoma. Tuba edema and purulent secretion were significantly more common in these patients (Tables 2, 3) $(\mathrm{p}<0.0005)$.

The male-to-female ratio was similar to the patients with inactive COM (Figure 2). Half of these patients had various types of otitis media and sequela in the corresponding ears. The mean age was 25.2 lower than the other COM types (Table 1). Nasopharyngeal pathologies were more frequent in inactive COM patients. Tuba edema, 


\begin{tabular}{|c|c|c|c|c|c|c|c|c|c|c|c|c|c|}
\hline \multicolumn{14}{|c|}{ Table 2} \\
\hline & \multicolumn{2}{|c|}{$\begin{array}{l}\text { Children with } \\
\text { OME }(\mathrm{n}=27)\end{array}$} & \multicolumn{2}{|c|}{$\begin{array}{l}\text { Adults with } \\
\text { OME }(\mathrm{n}=9)\end{array}$} & \multicolumn{2}{|c|}{$\begin{array}{l}\text { COM with } \\
\text { cholesteatoma }(n=22)\end{array}$} & \multicolumn{2}{|c|}{$\begin{array}{l}\text { Inactive } \\
\operatorname{COM}(\mathrm{n}=34)\end{array}$} & \multicolumn{2}{|c|}{$\begin{array}{l}\text { Suppurative } \\
\text { COM }(n=11)\end{array}$} & \multirow{2}{*}{$\frac{\begin{array}{c}\text { Control } \\
\text { adult }(n=100)\end{array}}{n}$} & \multicolumn{2}{|c|}{$\begin{array}{c}\text { Control } \\
\text { children }(n=24)\end{array}$} \\
\hline & $\mathrm{n}$ & $\%$ & $\mathrm{n}$ & $\%$ & $\mathrm{n}$ & $\%$ & $\mathrm{n}$ & $\%$ & $\mathrm{n}$ & $\%$ & & $\mathrm{n}$ & $\%$ \\
\hline Normal nasopharynx & 2 & 7.4 & 2 & 22.2 & 10 & 45.45 & 13 & 38.2 & 1 & 9.09 & 66 & 8 & 33.3 \\
\hline Edema & 2 & 7.4 & 4 & 44 & 8 & 36 & 14 & 41.17 & 7 & 63.6 & 4 & 0 & 0 \\
\hline Compression by adenoid tissue & 23 & 85 & 2 & 22.2 & 7 & 31.8 & 13 & 38.2 & 4 & 36.3 & 18 & 15 & 62.5 \\
\hline Purulent discharge & 12 & 44 & 6 & 66 & 3 & 13.63 & 5 & 14.7 & 6 & 54.5 & 2 & 2 & 8.33 \\
\hline Atrophy & 0 & 0 & 0 & 0 & 0 & 0 & 1 & 2.9 & 0 & 0 & 2 & 0 & 0 \\
\hline Tumor & 1 & 3.7 & 0 & 0 & 0 & 0 & 0 & 0 & 0 & 0 & 1 & 1 & 4.16 \\
\hline Normal nasal cavity & 12 & 44 & 3 & 33.3 & 11 & 50 & 14 & 41.17 & 2 & 18.18 & 50 & 17 & 70.8 \\
\hline Septal deviation & 7 & 25.92 & 4 & 44 & 6 & 27.7 & 17 & 50 & 5 & 45.4 & 29 & 2 & 8.33 \\
\hline Concha hypertrophy & 1 & 3.7 & 1 & 11.11 & 1 & 4.5 & 2 & 5.88 & 0 & 0 & 11 & 2 & 8.33 \\
\hline Sinusitis/polyp & 7 & 25.92 & 3 & 33.3 & 1 & 4.5 & 1 & 2.9 & 4 & 36.36 & 7 & 1 & 4.16 \\
\hline Nasal allergy & 0 & 0 & 1 & 11.11 & 0 & 0 & 0 & 0 & 0 & 0 & 4 & 4 & 16.6 \\
\hline
\end{tabular}

purulent secretion and septal deviation were the most frequent endoscopic findings.

The sex rate was similar to suppurative COM patients. Half of these patients had various types of otitis media and sequela in the corresponding ears. The mean age was 33.55 which was similar to those with other COM (Table 1).

Nasopharyngeal pathologies (Figure 3) were more frequent in suppurative COM patients. Tuba edema and purulent secretions, particularly were found to be highly significant in these patients $(\mathrm{p}<0.0005)$. Sinusitis was also significantly higher $(\mathrm{p}<0.005)$.

\section{DISCUSSION}

Endoscopy is the only examination method which allows direct visualization of the nasal cavity and nasopharynx. ${ }^{[3]}$ It is particularly helpful for the diagnosis of nasal cavity and nasopharyngeal pathologies. ${ }^{[7]}$
Today, factors and pathologies which are responsible for etiopathogenesis of otitis media have been evolving in favor of patient demographics. ${ }^{[5]}$ Previous studies mostly reported bilateral OME in children and males, particularly. ${ }^{[8]}$ There are many studies on the etiopathogenesis of OME in children in the literature. In earlier years, masses such as adenoid tissues in the nasopharynx might be considered likely to cause effusion, since a nasopharyngeal mass was an obstacle to air flow through the ET, creating a negative pressure in the middle ear followed by an effusion. ${ }^{[3]}$ However, later studies showed that there was no relationship between the size and weight of the adenoid tissue and OME.${ }^{[4]}$ In addition, Phillips et al. ${ }^{[8]}$ reported that there was no difference in the adenoid depth at varying ages between the study and control groups. However, the authors reported a significantly smaller palatal airway measurement in the bilateral glue ear group based on age-adjusted estimations. In another study, Stenfors

Table 3

Comparison of the endoscopic findings in patients with otitis media and control subjects

\begin{tabular}{|c|c|c|c|c|c|c|c|c|c|c|}
\hline & \multicolumn{2}{|c|}{ Children with OME } & \multicolumn{2}{|c|}{ Adults with OME } & \multicolumn{2}{|c|}{$\mathrm{COM}$ with cholesteatoma } & \multicolumn{2}{|c|}{ Inactive COM } & \multicolumn{2}{|c|}{ Suppurative COM } \\
\hline & $\mathrm{t}$ & $p$ & $\mathrm{t}$ & $p$ & $\mathrm{t}$ & $p$ & $\mathrm{t}$ & $p$ & $\mathrm{t}$ & $p$ \\
\hline Normal nasopharynx & 2.327 & $<0.025$ & 2.06 & $<0.025$ & 1.909 & $<0.05$ & 3.11 & $<0.005$ & 3.75 & $<0.0005$ \\
\hline Edema & $\mathrm{x}$ & $\mathrm{x}$ & 5 & $<0.0005$ & 4.63 & $<0.0005$ & 6.19 & $<0.0005$ & 62.105 & $<0.0005$ \\
\hline Compression by adenoid tissue & 1.88 & $<0.05$ & 0.3 & $>0.1$ & 1.44 & $>0.05$ & 1.81 & $<0.05$ & 1.4492 & $>0.05$ \\
\hline Purulent discharge & $\mathrm{x}$ & $\mathrm{x}$ & 8 & $<0.0005$ & 2.75 & $<0.0005$ & 3.1 & $<0.005$ & 37.14 & $<0.0005$ \\
\hline Normal nasal cavity & 2.03 & $<0.025$ & 0.98039 & $>0.1$ & 0 & $>0.1$ & 1 & $>0.1$ & 2.13333 & $<0.025$ \\
\hline Septal deviation & 1.76 & $<0.05$ & 1 & $>0.1$ & 0.17 & $>0.1$ & 4.2 & $<0.0005$ & 1.14 & $>0.1$ \\
\hline Choncha hypertrophy & $\mathrm{x}$ & $\mathrm{x}$ & 0.101009 & $>0.1$ & 1.16 & $>0.1$ & $\mathrm{x}$ & $\mathrm{x}$ & $\mathrm{x}$ & $\mathrm{x}$ \\
\hline Sinusitis & 2.1 & $<0.025$ & 1.04 & $>0.1$ & 0.54 & $>0.1$ & 1.51 & $>0.05$ & 3.222 & $<0.005$ \\
\hline
\end{tabular}




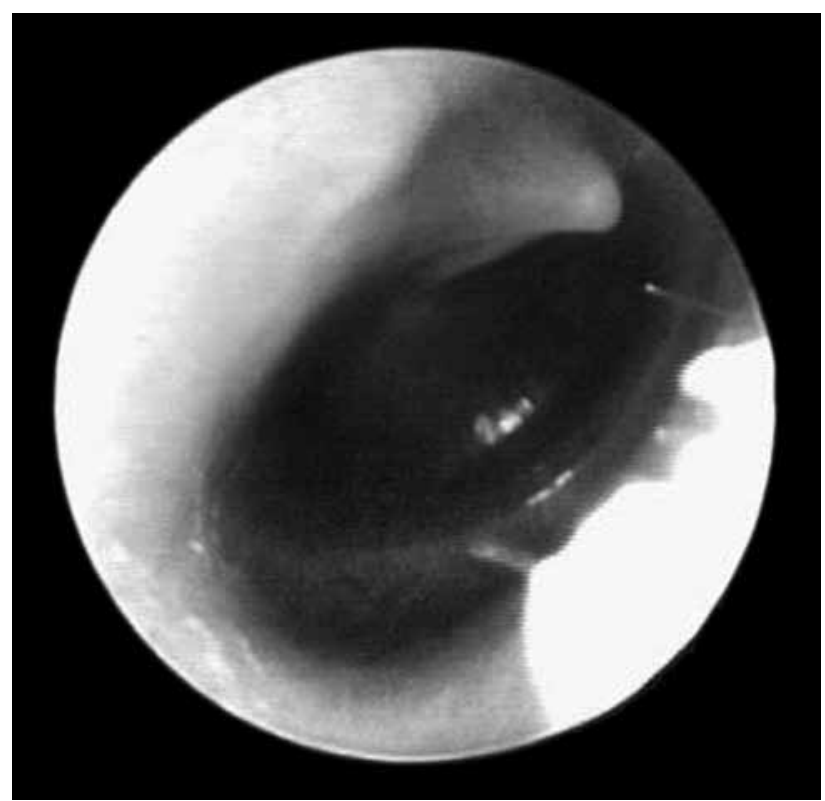

Figure 1. Otitis media with effusion.

and Räisänen ${ }^{[9]}$ proposed that accumulation of a sticky glue effusion material in the middle ear cavity might serve as a barrier against ascending pathogens from the nasopharynx.

Inconsistent with the previous data, a study reported that the size of adenoid and tumor and polyps in the nasopharynx did not lead to otitis media by applying external pressure to ET. ${ }^{[10]}$ The authors showed that adenoid tissue, polyps and tumors in the nasopharynx might lead to dysfunction by affecting the ET-function mediated muscles. ${ }^{[3,11]}$

Furthermore, previous studies suggested a close relationship among adenoid inflammation, nasopharyngeal microorganisms and OME. ${ }^{[4,11]}$ Suzuki et al. ${ }^{[4]}$ reported that adenoid inflammation was implicated in the pathogenesis of $\mathrm{OME}$ and the adenoids might have an important role in the etiology of OME, as being a reservoir for Haemophilus influenzae. There was no significant difference in the size of adenoids. Haemophilus influenzae was cultured more frequently in adenoid specimens from patients with OME. In addition, nasopharyngeal microorganisms; Haemophilus influenzae, Streptococcus pneumonia and Moraxella catarrhalis otitis are similar in otitis media. Otitis media with effusion is closely correlated to the presence of middle ear pathogens in the nasopharynx. ${ }^{[5,11]}$ Based on these finding, tuba edema and purulent secretion in nasopharynx accompanied by sinusitis were significantly higher, while the size of adenoid vegetation were not significant between the children with OME and controls. This may be a strong evidence for Wang et al. $^{[12]}$ reported that major pathological findings

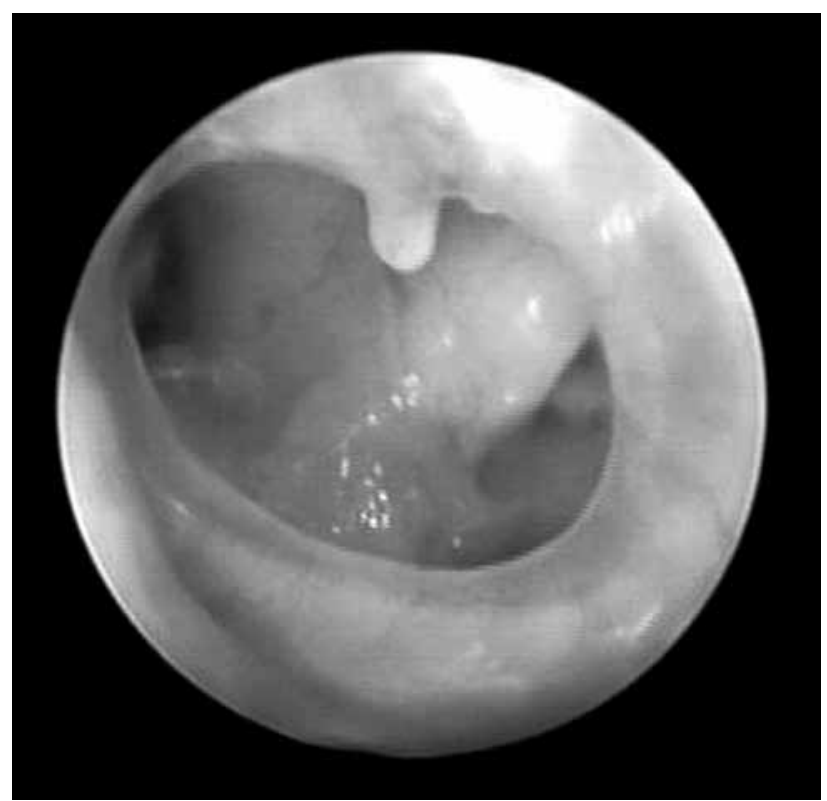

Figure 2. Inactive chronic otitis media.

associated with tubal dysfunction were nasopharyngeal inflammation. The authors showed that the eustachian tube isthmus was narrowed by trans-eustachian tube endoscopy in COM. Abnormal tube mycoses were also more common in cholesteatoma patients. Abnormal mucus may result in an increased risk of chronic disease in the long-term and individual treatment should be tailored accordingly. ${ }^{[5]}$

Moreover, viral or bacterial infections of the upper airway are not only associated with AOM, but also with chronic suppurative otitis media. In the past, nasal obstruction secondary to rhinitis, deviated septum, polyps and sinusitis were associated with OME. ${ }^{[13]}$ In this study, the Toynbee phenomenon may be responsible

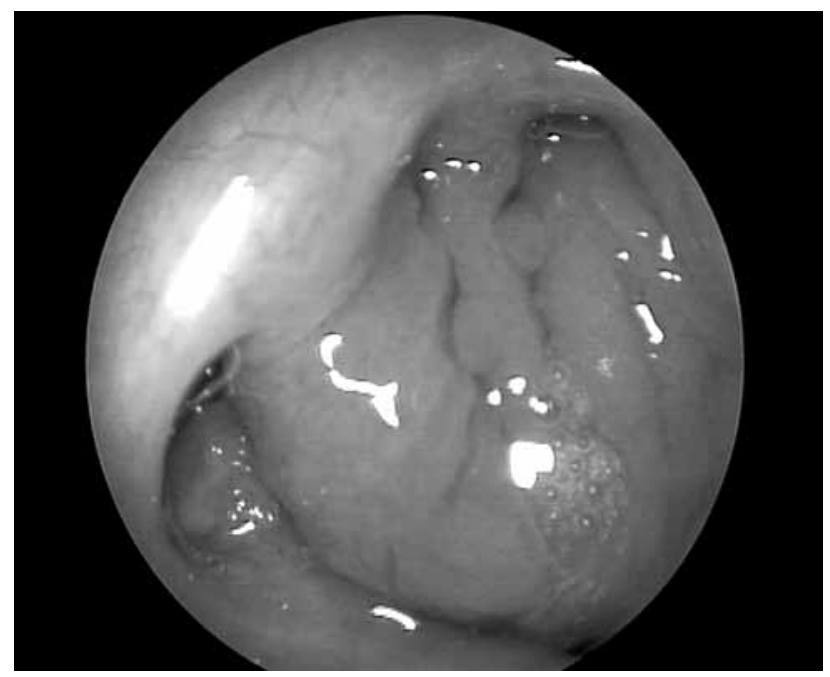

Figure 3. Adenoid tissue. 
for the pathogenesis of OME in our patients. When the nose is obstructed initially, swallowing produces a positive air pressure followed by a negative one, which may result in insufflations of contaminated secretions from the nasopharynx in to the middle ear in the presence of negative middle ear pressure particularly. ${ }^{[13]}$

So far, three mechanisms were postulated that airflow turbulence in the postnasal space may lead to ET dysfunction. ${ }^{[14]}$ Firstly, airflow turbulence may lead to deposition of microorganisms and air pollutions in the region of the ET opening, resulting in tubal epithelial or peritubal inflammation and mechanical obstruction of the ET. Secondly, the drying effects of altered air currents due to increased tubal opening pressure may increase tubal mucus viscosity and surface tension. Thirdly, postnasal mechanic-receptors and an autonomic nerve supply to the ET have been described. Altered air currents may stimulate these mechanicreceptors leading to reflex alteration of ET function. Low and Willatt ${ }^{[14]}$ concluded that middle ear pressure ipsilateral to the obstructed nasal passage was negatively correlated to the degree of asymmetry of the potencies of the two nasal passages. Surgical septal correction of this asymmetry produced a corresponding improvement in middle ear pressure.

It has been also shown that, nasal obstruction may influence the middle ear pressure, by altering the function of the ET. ${ }^{[15,16]}$ Adults, in particular, experimentally infected with rhinovirus or influenza virus developed significant nasal obstruction and a subset of these patients had abnormally high positive middle ear pressures lasting throughout the period of illness.

While nasal obstructions result from viral upper respiratory infection and nasal allergy of OME, the predictive value of nasal obstruction in the pathogenesis of OME remains unclear. ${ }^{[16]}$ The results of clinical studies indirectly support a causal relationship between them. On the contrary, Buchman et al. ${ }^{[16]}$ showed that no evidence of otitis media was documented in ferrets with unilateral or bilateral nasal obstruction, and the tubal function tests used showed only the expected effects of the altered middle ear nasopharyngeal pressure gradients resulting from the experimental nasal obstruction.

In our study, only COM patients had a significantly higher rate of septal deviation. We suggest that septal deviation may have a role in the pathogenesis of otitis, however, might not be directly effective in the management of suppuration.

In conclusion, endoscopic nasal cavity and nasopharyngeal examination results are of utmost importance for the evaluation of the patients with otitis media. The pathologies found in these cases may play a role in the etiopathogenesis, particularly in suppurative otitis. The diagnosis and treatment of these nasal or nasopharyngeal pathologies would provide invaluable benefits for the treatment and prognosis of otitis media.

\section{Declaration of conflicting interests}

The authors declared no conflicts of interest with respect to the authorship and/or publication of this article.

\section{Funding}

The authors received no financial support for the research and/or authorship of this article.

\section{REFERENCES}

1. Cunningham M, Guardiani E, Kim HJ, Brook I. Otitis media. Future Microbiol 2012;7:733-53.

2. Cassano P, Cassano M. Otitis media and immunological alterations of Waldeyer's ring. Otorhinolaryngol 2011;72:164-9.

3. Sadé J. The nasopharynx, eustachian tube and otitis media. J Laryngol Otol 1994;108:95-100.

4. Suzuki M, Watanabe T, Mogi G. Clinical, bacteriological, and histological study of adenoids in children. Am J Otolaryngol 1999;20:85-90.

5. Linstrom CJ, Silverman CA, Rosen A, Meiteles LZ. Eustachian tube endoscopy in patients with chronic ear disease. Laryngoscope 2000;110:1884-9.

6. Kurien M, Lepcha A, Mathew J, Ali A, Jeyaseelan L. $\mathrm{X}$-Rays in the evaluation of adenoid hypertrophy: It's role in the endoscopic era. Indian J Otolaryngol Head Neck Surg 2005;57:45-7.

7. Ezzat WF. Role of endoscopic nasal examination in reduction of nasopharyngeal adenoid recurrence rates. Int J Pediatr Otorhinolaryngol 2010;74:404-6.

8. Phillips DE, Maw AR, Harvey K. The nasopharynx and adenoid in children with glue ear compared with normal controls. Clin Otolaryngol Allied Sci 1987;12:255-60.

9. Stenfors LE, Räisänen $S$. Quantitative analysis of the bacterial findings in otitis media. J Laryngol Otol 1990;104:749-57.

10. Kindermann CA, Roithmann R, Lubianca Neto JF. Obstruction of the eustachian tube orifice and pressure changes in the middle ear: are they correlated? Otol Rhinol Laryngol 2008;117:425-9.

11. Stenfors LE, Räisänen S. Bacterial attachment in vivo to epithelial cells of the nasopharynx during otitis media with effusion. J Laryngol Otol 1992;106:111-5.

12. Wang D, Clement P, Kaufman L, Derde MP. Fiberoptic examination of the nasal cavity and nasopharynx in children. Int J Pediatr Otorhinolaryngol 1992;24:35-44.

13. Sismanis A. Otitis media: the pathogenesis approach. Assessment and treatment of associated upper respiratory tract pathology. Otolaryngol Clin North Am 1991;24:947-55. 
14. Low WK, Willatt DJ. The relationship between middle ear pressure and deviated nasal septum. Clin Otolaryngol Allied Sci 1993;18:308-10.

15. Glynn F, Keogh IJ, Ali TA, Timon CI, Donnelly M. Routine nasopharyngeal biopsy in adults presenting with isolated serous otitis media: is it justified? J Laryngol Otol 2006;120:439-41.

16. Buchman CA, Doyle WJ, Swarts JD, Bluestone CD. Effects of nasal obstruction on Eustachian tube function and middle ear pressure. Acta Otolaryngol 1999;119:351-5. 